\author{
Dr. Zofia Łapniewska \\ zofia.lapniewska@uj.edu.pl \\ Review of Radical Political Economics, SAGE \\ DOI: $10.1177 / 0486613415616217$
}

\title{
(Re)claiming Space by Urban Commons
}

\begin{abstract}
The purpose of this research is to analyse the process of (re)constitution of urban commons by actors involved in action situations. What follows is a description of the way in which these actors are organised and (re)claim urban space, asserting their rights to the city, in relation to the introduced framework. For my analysis of two initiatives in Poland I propose the approach of Elinor Ostrom and address its limitations and critiques as well as outline further areas of research.
\end{abstract}

\section{Introduction}

Urban Commons, defined as physical urban spaces or services which are considered "community goods" or "local common goods" (Kassa 2008; Foster 2011; Harvey 2012; laione 2012), could be perceived as moving beyond the narrow definition of dichotomous state/private property rights. Collectives, communities, informal groups and other governance structures (Williamson 1996) that manage urban commons give them different meanings (Castells 1983). Commons are also subject to transformations over time, due to not only changes of the attributes of the physical world but also actors, action situations and patterns of interaction. These elements of a system are discussed in this paper in relation to two Polish urban commons: housing services in Kraków and Participatory Budget (Budżet Obywatelski) in Sopot.

Karl Polanyi in his book The Great Transformation, written just after the Great Depression, pointed out that imposing unnatural market logic on the society leads to resistance against commodification, marketization and privatization, which in turn creates a countermovement for protecting the society from exploitation, alienation and displacement (Polanyi 1957: 130; Hardt and Negri 2009: 124). Since Polanyi's 
book has been published, two more phenomena emerged that make his work still relevant today: commodification of nature and commodification of knowledge (Jessop 2002). In this double movement urban communities, which take forms of collectives or informal groups, can play an active role as an example of a model of social organization, based on values and motivations other than rationality and selfinterest of homo economicus. Today, two decades after a neoliberal political course was introduced in Poland, the growing number and variety of commons, actively (re)claiming places and spaces, shows that their role in calling attention to principles of cooperation, empathy and social goals in society's development cannot be disregarded.

Urban commons are a reflection of an open urban space that originates from the first Greek citystates (Rewers 2005: 10). Aristotle in his first book of Politics, in the polemics with Plato, describes people as human beings without equal rights. To overcome these disparities people created community and called it "polis", where they could meet as equal citizens. The aim of that community was to strive for the common good (Aristotle 1984). However, it is important to mention that the "common good" described by Aristotle is nowadays disputed as it did not include the voices of women, slaves and children, who were not perceived as "citizens" at that time. The modern concept of a city as a social, cultural and spatial phenomenon which brings together individual and collective practices has evolved not only from the ideas of the Greek polis but also from Cartesian urban ratio, Enlightenment's industrial efficiency and secularism (Paetzold 1996: 2000). These concepts created underpinnings of the urban studies conducted among others by Lewis Mumford, Max Weber, Georg Simmel, Walter Benjamin, Henri Lefebvre, David Harvey and many other scientists from different academic disciplines. Today, these studies emphasize and discuss, among others, rights to the city, which are an important feature of this paper. The idea of the rights to the city was initially described by Henri Lefebvre in his text Le Droit à la ville (1967). To his mind rights to the city mean the "access to urban life" which is closely related to the culture approach to the city. Within this current of thought one Polish sociologist Aleksander Wallis (Wallis 1967) stresses not only the importance of architecture or divisions of city's territory but also its social functions. David Harvey extends that perception through relating it to the collective subjects and emphasizing their agency:

The right to the city is far more than the individual liberty to access urban resources: it is a right to 
change ourselves by changing the city. It is, moreover, a common rather than an individual right since this transformation inevitably depends upon the exercise of a collective power to reshape the processes of urbanization. The freedom to make and remake our cities and ourselves is, I want to argue, one of the most precious yet most neglected of our human rights. (Harvey 2008: 23)

The definition of rights to the city above corresponds with the phenomena of creation and governance of urban commons in the light of transforming urban spaces and places. Their meaning and framework for an analysis devised by Elinor Ostrom will be discussed in the subsequent paragraphs.

\section{Urban Commons}

Urban commons range from local parks, gardens, squares, local streets and public spaces (Foster 2011: 57-58, O'Brien 2012: 467-468) to a number of services such as public transportation, water service, urban health, gas and electric distribution with their facilities (laione 2012: 114). These commons are very often created by local communities as a response to market and state failure in delivering quality goods and services. Citizens organize themselves and change the environment they live in by simulating imaginary cities they would like to inhabit. As Richard Sennett notes, "cities everyone wants to live in should be clean and safe, possess efficient public services, be supported by a dynamic economy, provide cultural stimulation, and also do their best to heal society's divisions of race, class and ethnicity" (Sennett 2006). To transform cities into such places the efforts put in space modifications have to be undertaken collectively. Mancur Olson, in his book published more than half a century ago, describes a variety of functions fulfilled by way of involvement in a collective action (1971[1965]: 16-43). Traditionally, particular group interests were solely those of the groups of kin or other types of family units. However, as society developed, some of these functions have been taken over by organized associations and solidarity groups. Depending on the organization's type it could satisfy the demands, meet the needs or further the interests of its members. "[A]ny group or organization, large or small, works for some collective benefit that by its very nature will benefit all the members of the group in question" (Olson 1971[1965]: 21). Thus, people in groups have their individual and common incentives to act collectively as well as realize their own potential in actions taken.

Ralph H. Turner (1983) interprets a collective action (also called a "commoning practice" (Harvey 2012: 73)) as meaningful behaviour which has its internal logic, requires specific relational structures and 
defined decision-making mechanisms. The author emphasizes that in order for a collective action to be successful, one needs to set clear goals and design an information flow that would include outcomes calculation, accumulation of knowledge and experiences as well as learning from the past. Alberto Melucci adds that collective behaviour can manifest itself in the form of common objectives and shared values in response to specific dysfunctions of the social system, hence a collective set of representations is created in order to fuel a given action (Melucci 1996: 15). Melucci as well as Donatella della Porta and Mario Diani (2006) raise a number of questions regarding the analysis of collective actions, starting with the definition of process that gives rise to a common action, the components of its structure within social environment and finally the relations between actors influencing its continuity, effectiveness and adaptability. Equally important are the characteristics of individual actors of a community, among other activists, intellectuals and artists, and their role as major agents of critical values and cultural change (Porta and Diani 2006: 8687). The features mentioned above are reflected in the design principles and framework for Institutional Analysis and Development proposed by Elinor Ostrom and introduced in the next section of this paper.

Local communities have different motivations to manage urban commons, in the sense of both the material and immaterial common goods (laione 2012: 114). For instance, by managing urban gardens people use spaces that would otherwise be a wasteland, protect their local environment and at the same time produce fruit and vegetables for their own use. On the other hand they cultivate intangible common goods such as social relationships, empathy, mutual help and the psychophysical well-being from experiencing nature. Both tangible and intangible goods in this case comprise a picture of living in the city of a higher standard than could be offered by the dominant capitalist model that is focused on competition, materialism and isolation (Nelson 2003).

Different urban settings managed directly by urban communities are diverse in terms of characteristics of the resource used. Also, collectives vary among themselves in setting collective action goals, forming community representation, decision-making processes, application of rules and having disparate attributes of communities and spatial practices. However, empirical studies demonstrate that successful groups are able to overcome internal problems and manage common-pool resources, as well as sustain them over time without the enforcement of an external Leviathan (Ostrom 1990; Bollier and 
Helfrich 2012). As stated above, commons often emerge in situations defined by Sheila R. Foster as "regulatory slippage", i.e. when the local government or private owner management of a resource vanish for various reasons, including rational choice of abandonment in case of high costs of maintenance, control and restrictions enforcement (Foster 2011: 66-70); in many cities the authorities intentionally allot some public space for common use. Therefore, what used to be clearly defined in state/private division of property rights regimes fades away, leaving space for other forms of ownership. Apart from categories of private goods and club goods that are highly excludable, Elinor Ostrom describes open-access public goods and common-pool resources, indicating differences and similarities between them (Ostrom 2005a: 24). Both Elinor Ostrom and Daniel W. Bromley (1992) point out that open access (non-property) goods with benefit stream available to anyone, but at the same time depletable, might be exposed to crowding, over-use and devastation, leading to the "tragedy of the commons" as described by Garret Hardin (Hardin 1968). They also indicate that in the case of common property regime, when a group of people sets norms, rules and shared strategies (called "institutions"), it can create a robust common-pool resource used in a way that was designed and accepted by the community. Lively urban commons can be, therefore, sustained over time without the necessity of transferring the ownership into state or private hands. Communities can extend the boundaries of resources to include non-members and by this act further blur the division between open-access and common goods. The framework presented below is suitable for this diversity of resources as well as institutions created to govern them.

\section{Framework for Analysis}

Elinor Ostrom proposes design principles for institutions of resilient self-governing common-pool resources, aimed at helping them prevent resource exhaustion and avoid free-riding and conflicts, which can be implemented in both rural and urban settings. These are: "clearly defined boundaries, congruence between appropriation and provision rules and local conditions, collective-choice arrangements, monitoring, graduated sanctions, conflict-resolution mechanisms, minimal recognition of rights to organize and nested enterprises for common-pool resources that are parts of larger systems" (Ostrom 1990: 90). These guidelines were formulated upon examination of various case-studies and their institutional 
performances (robust, fragile or failure). Additionally, for the evaluation and design of institutional arrangements which can improve the governance and management of a resource, Elinor Ostrom provides a framework for Institutional Analysis and Development (IAD) (Ostrom 1998: 68-90; 2005: 13-29). The IAD framework (presented in Figure 1) can be useful in diagnostics, analysis and prescriptions for facilitating the organization of commons. "It focuses on how rules, physical and material conditions and community attributes shape action arenas and incentives faced by individuals, and hence how these conditions combine to determine outcomes" (Ostrom 1998: 68).

Figure 1. A framework for institutional analysis (IAD)

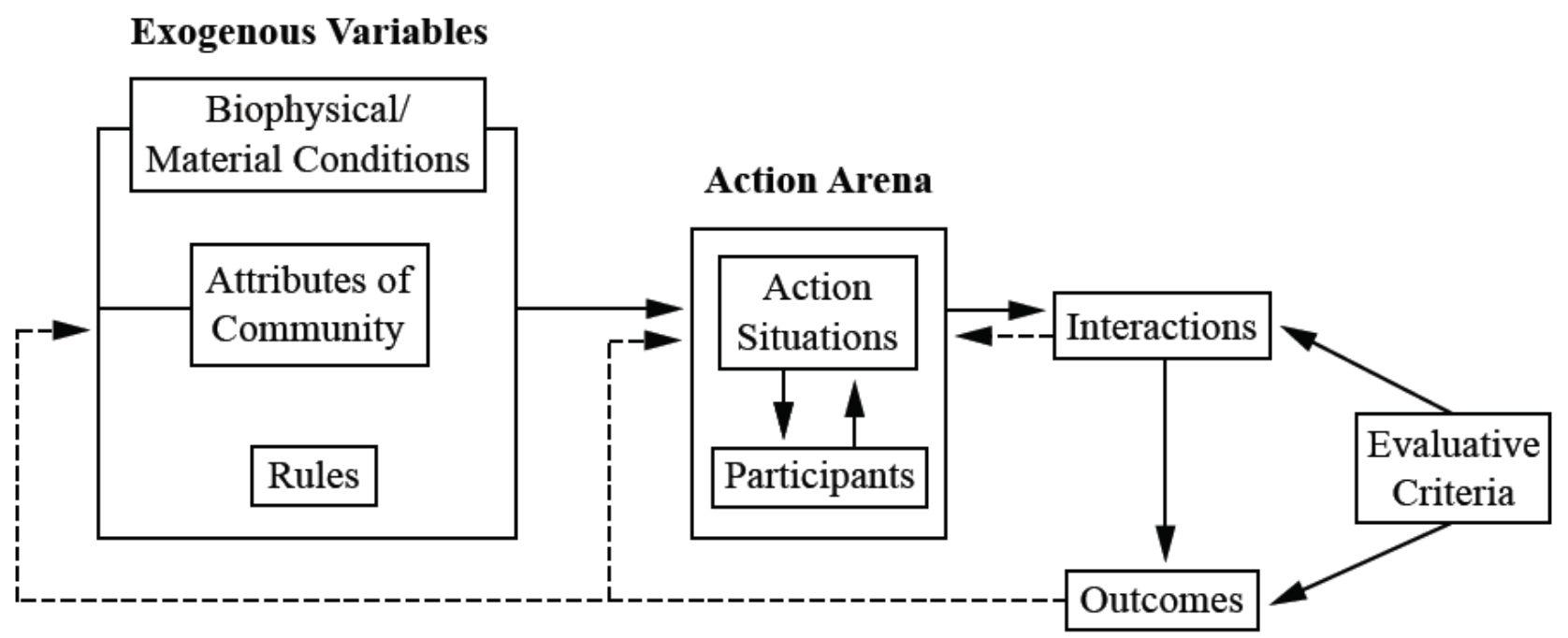

Source: Ostrom 2005a: 15.

The understanding of institutions and the process of institutional change in the selected case studies ("Rights to the City" initiative and Participatory Budget) are fundamental in understanding their economic, social and ecological performance. The IAD framework presented above provides insight into complex relationships between, in Ostrom's terms, "actors" in "action situations" in the "action arena" (Ostrom 2005a). According to Elinor Ostrom, Roy Gardner and James Walker, action arena is a conceptual unit that becomes "the focus of analysis, prediction, and explanation of behaviour and outcomes within fixed constraints" (Ostrom, Gardner and Walker 1994: 28). Action arena includes two components: action situation (the social space for interactions) and actors. These elements will be extracted for the selected 
case-studies in the next section. Participants, as subjects who develop, design and maintain institutions, are the central concern of the presented graph as well as in other approaches, i.e. Actor-Centered Institutionalism of Fritz W. Scharpf (1997: 44), Institutions of Sustainability of Konrad Hagedorn (2008) and Socio-Ecological Systems Framework of Elinor Ostrom (2009).

Institutions and governance structures (contracts, networks, bureaucracy, cooperation or markets) are organisational solutions that make institutions effective and can be deliberately designed by people or may emerge spontaneously through self-organisation (Hagedorn 2008: 359-360). Changes in the institutional environment and governance structures may affect resource allocation, and in a longer term influence community values. Samuel Bowles in his article on endogenous preferences shows that the economic institutions such as markets do not only allocate goods and services but also "influence the evolution of values, tastes and preferences" (Bowles 1998: 75). The preferences as "attributes of individuals that (along with their beliefs and capacities) account for the actions they take in a given situation" (Bowles 1998: 78) can be viewed in the Ostrom's framework above (Fig. 1) as forming action arenas. Bowles also remarks in reference to findings of Robert B. Edgerton, Paul E. Breer and Edwin A. Locke that if markets and economic institutions influence tasks people perform, they may shape preferences that are generalized to other than work realms of life (Bowles 1998: 96-97). This, in turn, can lead to deliberations on an opposite phenomenon - an extent to which commoning practices affect dispositions and attitudes toward markets and economic institutions and willingness to create alternative, collective economic practices based on solidarity. Bowles does not join this discussion, limiting himself to acknowledging that "approximating the market ideal by perfecting property rights may weaken non-market solutions to problems of social coordination" (Bowles 1998: 104). Property rights and non-market solutions will be addressed in reference to two case studies of urban commons presented in the next section.

\section{Examples of Polish Urban Commons}

As an illustration of the theories described in previous paragraphs I have chosen two grassroots initiatives in Poland: "The Rights to the City" initiative (Inicjatywa „Prawo do miasta”) from Kraków and Participatory Budget (Budżet Obywatelski) in Sopot. They represent different interests of inhabitants, 
pertain to various resources and take place in two cities of different sizes (Kraków - more than 750,000 inhabitants and Sopot - less than 40,000) and location (Kraków in the South and Sopot in the North). Yet, the principles of both include citizens' rights to make decisions about the city, about both its tangible and intangible resources.

The initiatives presented in this paper can be recognized as local communities governing the urban commons because they meet the conceptual premises concerning their structure and attributes. Both groups are informal in character and, therefore, do not have hierarchical structures. They bring together citizens who want to be involved on a voluntarily basis. The governance structure can be qualified as flat and the group considered a collective. This form of organization lies beyond the typical structure of markets and hierarchies (Ostrom 2005b). The (re)claimed common-pool resources in these instances are housing services in Kraków and the Sopot budget. They emerged, as described at the beginning of this article, as a response to the intense commodification of goods and services, in a situation when local governments, deep in debt, have stepped aside and attempted to privatize their assets, at the same time commodifying citizens' standard of living. The two initiatives are also linked because of a demand for introducing the direct democracy principle into local governance - a principle that would enable citizens to take active part in managing urban places and spaces. This, in turn, refers to the aforesaid concept of "polis", struggles for the common good in ancient cities and shared rights to them among citizens.

Slogans referring to the improvement of the citizens' well-being have been brought up by the residents involved in "The Rights to the City" initiative in Kraków. This initiative was established in May 2012 during the occupation of the Main Market Square. The "Tent City" action, as the occupation was called, was registered by the Tenants Movement, however they were soon joined by various other groups including neighbourhood residents, students, academics, anarchists and trade unions representatives. Women and men of different ages and social status gathered to occupy the central square of the city for the first time in Kraków history. More than 100 people were involved in the "Tent City" action by day, with at least 15 participating by night ${ }^{1}$. The protesters discussed their demands, organized participatory workshops, open

\footnotetext{
1 "The Law of Assembly" of July 5, 1990 (Dz.U. $1990 \mathrm{Nr} 51$ poz. 297) states that "[a]n assembly is a gathering of at least 15 people, convened in order to debate or to jointly express their views". This definition was used by the municipality
} 
lectures and film screenings. The final demands formulated at that time touched upon not only housing problems and improvement of living conditions, but also included strong opposition to privatization and commercialization of culture, education and public property (Prawo do miasta 2013). From the outset the municipality was searching for loopholes that would put an end to the protest. The president of the city admitted later on that it was all done "in order [for us] not to be ashamed of a camp in the heart of the city, to be witnessed by foreign journalists who come for the UEFA European Championship" (FA 2012). Even though the "Tent City" occupation came to an end, "The Rights to the City" initiative continues its operations to this day. Looking after the tenants' affairs remains a primary concern of the initiative.

Kraków is one of the few cities in Poland only slightly affected by the Second World War, in that the urban tissue remained mostly untouched. After the war the housing sector was nationalized. Tenants were assigned to both old tenements and newly built blocks of flats. In 1990, after the economic system change, the government introduced a number of laws facilitating the privatization of flats. One such measure was that for a symbolic 1 PLN the tenants could purchase their flats, although it only applied to the housing built after the war. The owners of the old tenements in the city centre or their descendants could claim their property back. In some cases the equivalent monetary value was paid to the owners after the war. In the 1960s and 1970s the socialist government, on the basis of agreements signed with other countries, also paid compensation to Polish citizens abroad for the property acquired. Unfortunately, no records exist as far as these compensations go. As a result the tenants of pre-war tenements cannot purchase their flats (undetermined legal ownership), have to pay the exorbitant market price, equally unreasonable rents or they face eviction. Because the municipality has not invested much in social housing, the most disadvantaged have no place to move. At the same time many buildings in the city remain uninhabited, having been bought for speculative purposes. Since its formation in 2012 "The Rights to the City" initiative has actively engaged its members in, among others, the "housing round table" consultations with the

to deem the occupation illegal after three days, despite the fact that it was registered for seven. An employee of the city hall came at night to count the participants of the gathering, claiming that he or she could see only five people and as a result the organizers were ordered to remove the tents the following morning (from then on the number of protesters was a sensitive issue). The protesters did not comply, which fact resulted in a police intervention and forced removal of the tents. A few months later the initiative won the case in court, which acknowledged that "[i]t is unacceptable that quoting merely the number of required participants of the gathering is used to circumvent the regulations pertaining to its dissolution or even to harass its members". (Rąpalski 2012) 
municipality devoted to housing issues, blocked some forced evictions as well as organized lectures and workshops on rights to the city and participatory democracy. Recently, the initiative has been involved in debates on participatory budgets in all districts of Kraków (Inicjatywa "Prawo do miasta" 2015).

A year earlier, in 2011, the Participatory Budget (Budżet Obywatelski) was introduced in Sopot. It was conceived by the Sopot Development Initiative, an informal group established in 2008 by two friends Marcin Gerwin (political scientist) and Maja Grabkowska (social geographer). One of the issues discussed from the very outset was the introduction of the Participatory Budget (PB) in the city. Gerwin was inspired by various groups in the United Kingdom whose ambition is to dispense with consumer lifestyle and burning fossil fuels on the one hand, and on the other to set up urban gardens and promote renewable energy sources. On her part, Grabkowska had knowledge of and experience in working with local communities. They wanted to direct the citizens' attention to urgent problems with the ongoing unsustainable development of the city. Initially, they emphasized the importance of carrying out public consultations concerning changes in land development plans, including the renovation of the railway station and commercialization of green areas. Following the examples of other cities in Poland and abroad the group attempted to convince Sopot residents to take part in the social life on the local level as well as to influence decisions about their own environment.

In February 2009, the first meeting on participatory budgeting called "Democracy in Sopot" was organized for local inhabitants. Only a handful of residents showed up in the Secondary School No 2 in Sopot, where the meeting took place, among them two city councillors and the vice-president of the city.

The councillors were very surprised that one could work so closely with local residents. The whole idea of participatory budgeting, no one knew anything about that. It was new and abstract that people can decide for themselves. That is why we decided to organize a campaign. We drew up the "Democracy is not just elections" campaign and adopted a three-stage strategy. First, the simplest thing, a mechanism that would allow the residents to introduce resolutions. Currently, residents can register their draft of a resolution if they have collected 200 signatures (we suggested 50). It was simple, almost all of the councillors were in favour, the president also approved. The next step was streamlining the process of public consultation. It has not come to be thus far, mostly because there is a great deal of resistance. (Gerwin 2015)

The third step was the introduction of participatory budgeting. Before the local elections in 2010, the Sopot Development Initiative interviewed and recorded five candidates running for the position of the president 
of the city. One of the interview questions was about the consultations regarding participatory budgeting and its introduction. Four candidates were in favour of it, one against. The candidate who was against won the election. Simultaneously, paper questionnaires with similar questions were sent out to city councillors. "That was the time when councillors, at least some of them, familiarized themselves with the topic. At that time no information about civil/participatory budgets was available on the Internet in Polish" (Gerwin 2015). After the elections, two of the presidential candidates became councillors. Gerwin and Grabkowska initiated talks that were brought to a conclusion in May 2011 when the city council passed a resolution on the introduction of the Participatory Budget. “[First], not to rock the boat, a resolution, because we weren't sure if that could be passed as a bill. Then it turned out that many things could" (Gerwin 2015). The bill specified the amount of the budget subject to PB (equivalent of 1 percent of all the city expenditures ${ }^{2}$ ) and appointed a special committee of councillors to work on PB regulations. The committee worked during the summer holidays, meeting frequently and engaging in productive discussions.

In the meantime the president came up with the idea that he will set up his own participatory budget and was against organizing debates and meetings on this issue with the residents. Fortunately, in August one of the councillors who had the president's back went on holiday, another one didn't show up and suddenly the Civic Platform ${ }^{3}$ had a majority, voted their project in and voilà. Had this not taken place, I'm not sure how it would have ended. Maybe the president would have had his own consultations on this issue or his own participatory budget? (Gerwin 2015)

Today, Sopot is known as one of the pioneers of participatory budgeting in Poland. Every year, the residents vote on district and city-level projects and councillors have learned that projects that win are very concrete and useful - ideas such as funding and modernizing animal shelters, laying down bicycle paths, constructing new playgrounds, setting more benches and dustbins in parks, reconstructing the toboggan run, opening a day centre for the homeless and so forth. (Budżet Obywatelski 2015). The Sopot Development Initiative is still involved in monitoring and improving PB. Every year, a few members of the Initiative evaluate the process and write the recommendations to the city council. Some of those recommendations have been implemented, for example all the projects, their descriptions and implementation stage are listed on the

\footnotetext{
${ }^{2}$ Dedicating 1 percent of city expenses to PB has become a prevalent policy trend in many Polish cities. However, most budgetary expenses, such as administration costs, public debt costs, education subsidy, long-term investments etc. are fixed. The actual free amount that can be spent is not that high, therefore the share of PB amount in this remaining money for a disposal is much higher.

${ }^{3}$ Currently ruling party in Poland, representing centre of political scene.
} 
official website of the city. Other ideas, such as changing voting procedure or dividing the city into smaller districts have not been thus far approved (Gerwin 2015).

The actors introduced in both case studies discussed above are presented in the middle of Ostrom's conceptual framework (see Fig. 1). The action arena, in which the participants and action situation interact, is affected by the exogenous variables. These variables divide into "biophysical/material conditions" such as size of the resource or mobility of its units, "attributes of community" to which the term culture is frequently applied and finally "rules" concerning, among others, property rights in use. Daniel Bromley defines property rights as "a benefit (or income) stream, and [...] a claim to a benefit stream that some higher body - usually the state - will agree to protect through the assignment of duty to others who may covet, or somehow interfere with, the benefit stream" (Bromley 1992: 2). The benefits as well as duties in the studied examples officially belong to the state. The main conflict observed in these two cases is, therefore, the transfer of power from the local government representatives to the citizens' hands. As Gerwin asserts, "[w]e will not have a real democracy as long as we believe that 'the city authority' is a town or city mayor or councillors. [...] Although it happens that the mayor thinks that if he or she was elected, then he or she is in charge now, but it is a misunderstanding" (Gerwin 2012). Mirroring the spirit of this declaration, a new bill on local government in Poland was prepared by the Polish President's Office. It encourages municipalities to involve inhabitants in making key decisions. It can be perceived as an establishment of a new contract law that strengthens citizens' position and opens certain possibilities for them. Notwithstanding, the Participatory Budget in Sopot is called "social counsels" by the municipality, which lowers the rank of citizen's direct influence on, to put it into Harvey's words, "making and remaking the city".

The change of rules described above can influence the creation or emergence of rules-in-use and the definition of action arenas. The arenas in both cases consist of action situations such as protests, agreements and processes of shaping the groups of participants/actors involved; the structural rules used by those informal groups; the community attributes and material conditions. "The action arena is the social space within which individuals interact - exchange goods and services, solve problems, dominate one another, or fight" (Ostrom 1998: 68-69). The "Right to the City" Initiative fights for better living conditions of 
tenants, but also for a better standard of living of all Kraków inhabitants regardless of the house ownership status. In the case of the PB the decisions are taken by the local government but both benefits and costs are incurred by all citizens (as tax-payers). In this instance the property rights would not change if one were to introduce the direct democracy rule into the budgetary governance. However, the distribution of powers changes over time and a deeper analysis of this phenomenon may be of interest to researchers. Essentially, participatory budgets can constitute commons, following the model of Porto Alegre (Sintomer, Herzberg and Röcke 2005) where residents of particular districts decided upon investments of the district's budgetary means. The creation of budgets and investment plans had three dimensions there: the geographical basis, where the neighbourhood gatherings had a decisive voice, the thematic basis, where open gatherings and, later on, elected representatives of the districts monitored if the local investment plans are arranged in accordance with the general vision of city development, and finally the technical and programme basis, which included public administration (Górski 2007: 72). As a result, various actors representing local communities and the municipality have been, year after year, undertaking collective actions aimed at improving the well-being of Porto Alegre inhabitants, especially those of the poorer districts. The detailed analysis of the participatory budgeting in Porto Alegre between 1989-2004 indicates that it was not only "an experiment in economic democracy of world importance" (Marquetti, Schonerwald da Silva and Campbell 2012: 78) but it also allowed communities to learn about their rights and responsibilities, expanded the citizen's capabilities, lead to improved fiscal performance of governments and reduced corruption.

This is not to say participatory budgeting is without its limitations. The major ones in Porto Alegre were inadequate financial resources (less than 2 percent of city's GDP; similarly in Sopot - share of the PB in the city budget does not exceed 1.4 percent $^{4}$ ), poor commitment of the administration, the impediments of technical functioning of the budget and a narrow set of projects that can be taken up by the community (Marquetti, Schonerwald da Silva and Campbell 2012: 78-79). In Sopot, in their districts or in the city, the inhabitants can table a project which would normally be within the purview of the municipality. Similar to

\footnotetext{
${ }^{4}$ Gerwin (2015) explains that it is better now to have less money for citizens' projects because of the imperfections in their selection procedure - it helps to avoid accidental investments.
} 
Porto Alegre, most applications concern investments in infrastructure. These are mostly visible but small changes in city's tissue, easy to accept by most citizens. With the city's evolvement, however, social and ecological issues can come into stage and those can be more difficult to agree on. One of the principal problems of PB is also low citizen participation in voting on projects (only 15 percent of Sopot inhabitants in 2014 (Wyniki głosowania 2014)). This problem occurred as well during the first years of the participatory budgeting in Porto Alegre (less than a thousand inhabitants were involved in collective governing of the city in 1990), but year by year the number of registered members of the meetings grew substantially, to finally gather more than fifty thousand people in 2004 (Górski 2007: 89-90). Gerwin (2015) is also critical of the voting procedure in Sopot, deeming it too simple. Citizens are only asked to mark 3-5 projects they like from the list and not really compare the projects in any meaningful way. Negative voting is not possible, so there is no way to reject a project. Also, many votes are random because the residents do not acquaint themselves with projects or the projects are not described in detail. Even if the project is chosen for development, there is no guarantee that it will be completed (monitoring problems). Aside from the improvements introduced by the municipality (e.g. providing publicity for PB), there is still no serious dialogue with the residents about the future development of the city.

In the two Polish cases depicted in this paper the interactions between committed participants led to effective and successful outcomes, namely meeting the goals set by both collectives. Fulfilling the organizational and informative function, the groups managed to collect necessary information to carry out sufficient actions to change existing contracts (as well as social contracts) and to attract and involve a wider range of citizens in the cause. These positive results can encourage other local communities to manage their commons collectively. Furthermore, the increase of cooperation, reciprocity and the inclusion of the direct democracy rule in action situations can be an impulse towards creation of societies that are more equal, showing that different forms of organization are possible and they often respond to the citizens' needs more effectively. Elinor Ostrom's framework for institutional analysis (IAD) quoted herein served as an organizing principle for describing events and analysing their outcomes. The "actors" in "action situations" in the "action arenas" were introduced and actions and their effects discussed in a broader socio-political context. On the one hand, the framework made it easier to understand the events, on the other - it 
demonstrated the shortcomings of implemented changes.

\section{Discussion}

It is important to mention that collective actions do not always result in meeting the set goals. Institutions usually oscillate between stability and change and vary in terms of pace at different levels of social analysis, that is why an extended time reference needs to be taken into account in a comprehensive field-work study (North 1994). Conflicts and failures may emerge, putting the stability of a common in danger. Even the examples presented in this paper have their negative aspects. The "Tent City" at the Main Market Square in Kraków was "pacified" and Sopot initiative has been taken over by the municipality that shunted Sopot Development Initiative onto the sidelines. Magistrates not only control the process of submitting ideas to the $\mathrm{PB}$, but also through the promotion of the Participatory Budget they divert inhabitants' attention away from the remaining 98.6 percent of budgetary expenses.

Despite all the difficulties, the new commons are (re)claimed in urban spaces in many Polish cities. Most of them also occupy virtual space (the Internet), therefore their character is different than physical commons. Digital commons, defined as "software and hardware that is connected via the Internet" (Anderies and Janssen 2013: 137) include projects such as Wikipedia, social networks (Facebook, MySpace, Google+, etc.) or digital files (mostly with intellectual property). Since rivalry and exclusion are not part of their features and their scope of activities is not limited exclusively to the local community, these commons need different frameworks for analysis than the model presented herein, as they are to some extent limited to the examination of the physical common-pool resources and their governance (Hess and Ostrom 2007: 326).

Another problem of urban commons is the legal vacuum within which they operate. This causes, among other things, a lack of institutional stability, risk of changes to land development plans and the threat of eviction. However, some communities perceive the lack of statutory regulations as an advantage, as a narrow definition of "public/private" in relation to goods and services, understood also as imposing a set of rules, orders and bans, might limit their functions and range of actions. On the other hand, commons are often established simply as a response to an absence of markets and state services with an aim to meet 
the peoples' daily needs. They arise from the necessity or a defence against privatization of common assets (as a side of a double movement) rather than from a utopian belief that the world's goods and services can be run exclusively by collectives. As recent events have shown, many struggles over commons (e.g. Gezi Park in Istambul) turned into social movements demanding democracy, thus their importance should not be underestimated. The growing number and variety of commons shows the potential for institutional change in local spaces and services performed by local communities reclaiming rights to them. A further understanding and describing of the conditions as well as the process of the property rights transfer from private or state to community hands in the urban settings might therefore become the basis for interesting case-studies for future research, not only in Poland but all over the world, where despite different sociocultural factors people organize themselves to change the environment they live in.

\section{Conclusion}

The analysis presented in this paper is aimed at introducing a theoretical framework in relation to two grassroots initiatives that (re)constitute urban commons in Poland. Elinor Ostrom's concept focuses on detailed institutional analysis of observed modes of organization of physical goods and services, therefore its limitations have been shown and the directions of further research outlined. This paper is, more than anything else, an invitation to the discussion on Polish urban common-pool resources and collective actions of communities claiming rights to these resources. The analysis of performance of urban commons as alternative to market (private)/state dualism might constitute a valuable contribution to the discourse on future solutions for resources ownership and their management in cities.

\section{Acknowledgments}

I would like to thank reviewers for their insightful comments that help improve my paper, Stefan Łapniewski for his patience and excellent editing, and finally, my partner Katarzyna Puzon for her support through my academic journey. 


\section{Declaration of Conflicting Interests}

The author(s) declared no potential conflicts of interest with respect to the research, authorship, and/or publication of this article.

\section{References}

Anderies, J.M., and M.A. Janssen. 2013. Sustaining the Commons. Tempe: Center for the Study of Institutional Diversity, Arizona State University.

Aristotele. 1984. Complete Works of Aristotle, Volume 2: The Revised Oxford Translation, ed. J. Barnes. Princeton/ Bollingen Series LXXI 2.

Beckmann, V., and M. Padmanabhan. 2009. Analysing Institutions: What Method to Apply? In Institutions and Sustainability. Political Economy of Agriculture and the Environment - Essays in Honour of Konrad Hagedorn, eds. V. Beckmann and M. Padmanabhan, 341-371. Berlin: Springer.

Bollier, D., and S. Helfrich, eds. 2012. The Wealth of the Commons. A World Beyond Market and State. Amherst: Levellers Press.

Bowles, S. 1998. Endogenous preferences: The cultural consequences of markets on other economic institutions. Journal of Economic Literature 36: 75-111.

Bromley, D. W. 1992. The Commons. Common Property, and Environmental Policy. Environmental and Resource Economics 2: 1-17.

Budżet Obywatelski. 2015. Archiwum. Accessed $\quad$ January $\quad 12$, http://www.miasto.sopot.pl/strona/budzet_obywatelski

Castells, M. 1983. The City and the Grassroots: A Cross-cultural Theory of Urban Social Movements. Berkeley: University of California Press.

FA. 2012. Wałdze pacyfikujq okupację Rynku Głównego! Federacja Anarchistyczna Kraków. Accessed January 14, 2015. https://faKraków.wordpress.com/2012/05/21/trwa-okupacja-rynku-glownego/

Foster, S. 2011. Collective Action and the Urban Commons. Notre Dame Law Review 87(1): 57-134.

Gerwin, M. 2012. Władze miasta to mieszkańcy. Accessed October 6, 2013. http://www.sopockainicjatywa.org/2012/03/09/wladze-miasta-to-mieszkancy/

Gerwin, M. 2015. Telephone interview, January 12, 2015. 
Górski, R. 2007. Bez państwa: Demokracja uczestniczq̨ca w działaniu. Kraków: Korporacja Ha!art.

Hagedorn, K. 2008. Particular requirements for institutional analysis in nature-related sectors. European Review of Agricultural Economics 35(3): 357-384.

Hardin, G. 1968. The Tragedy of the Commons. Science 162(1968): 1243-1248.

Hardt, M., and A. Negri. 2009. Commonwealth. Cambridge, MA: The Belknap Press.

Harvey, D. 2008. The Right to the City. New Left Review 53: 23-40.

Harvey, D. 2012. Rebel Cities. From the Right to the City to the Urban Revolution. London: Verso.

Hess, Ch., and E. Ostrom. 2007. Introduction: An Overview of the Knowledge Commons. In Understanding Knowledge as a Commons. From Theory to Practice, eds. Ch. Hess and E. Ostrom, 3-26. Cambridge: MIT Press.

laione, Ch. 2012. City as commons. Accessed October 4, $2013 . \quad$ www.collectiveaction.info/conference/sites/default/files/laione_prelversion.pdf

Inicjatywa "Prawo do miasta". 2015. Accessed January $15,2015$. https://www.facebook.com/InicjatywaPrawoDoMiasta

Jessop, R. 2002. The Future of the Capitalist State. Cambridge: Polity Press.

Kassa, D. 2008. A Tragedy of the "Urban Commons"? A case study of 2 Public Places in Addis Ababa. Paper presented at the conference: Governing Shared Resources: Connecting Local Experience to Global Challenges, the Twelfth Biennial Conference of the International Association for the Study of Commons, Cheltenham, England, July 14-18.

Lefebvre, H. 1967. Le Droit a la Ville. L'Homme et la Societe 6: 29-35.

Marquetti, A., C.E. Schonerwald da Silva, and A. Campbell. 2012. Participatory Economic Democracy in Action: Participatory Budgeting in Porto Alegre, 1989-2004. Review of Radical Political Economics 44(1): 62-81.

Melucci, A. 1996. Challenging Codes: Collective action in the information age. Cambridge: Cambridge University Press. Nelson, J. 2003. Confronting the Science/Value Split: Notes on Feminist Economics, Institutionalism, Pragmatism and Process Thought. Cambrige Journal of Economics 27: 49-64.

North, D. 1994. Economic performance through time. American Economic Review 84: 359-368.

O'Brien, D. 2012. Managing the Urban Commons. The Relative Influence of Individual and Social Incentives on the Treatment of Public Space. Hum Nat 23: 467-489.

Olson, M. [1965] 1971. The Logic of Collective Action: Public Goods and the Theory of Groups. Cambridge: Harvard University Press. 
Ostrom, E. 1990. Governing the Commons. The Evolution of Institutions for Collective Action. Cambrige: Cambrige University Press.

Ostrom, E. 1998. The Institutional Analysis and Development Approach. In Designing Institutions for Environmental and Resource Management, eds. E. Loehman Tusak and M. Kilgour, 68-90. Cheltenham: Edward Elgar.

Ostrom, E. 2005a. Understanding Institutional Diversity. New Jersey: Princeton University Press.

Ostrom, E. 2005b. Doing Institutional Analysis. Digging Deeper Than Markets and Hierarchies. In Handbook of New Institutional Economics, eds. C. Menard and M.M. Shirley, 819-848. Berlin: Springer.

Ostrom, E. 2009. A General Framework for Analyzing Sustainability of Social-Ecological Systems. Science 325: 419-422.

Ostrom, E., R. Gardner, and J. Walker 1994. Rules, Games, and Common-Pool Resources. Ann Arbor: The University of Michigan Press.

Paetzold, H. 1996. The Philosophical Notion of the City. In City Life: Essays on Urban Culture, ed. H. Paetzold. Maastricht: Jan Van Eyck Academie.

Paetzold, H. 2000. Symbol, Culture, City. Maastricht: Jan Van Eyck Academie.

Polanyi, K. 1957. The Great Transformation. Boston: Beacon Press.

Porta, D., and M. Diani. 2006. Social Movements. An Introduction. 2nd ed. Cornwall: Blackwell Publishing.

Prawo do miasta. 2013. Kraków to nie firma, miasto to my! Accessed October 4, 2013. http://prawodomiasta.wordpress.com/2012/05/27/hello-world/\#more-1

Rąpalski P. 2012. Kraków: niesłuszna likwidacja pikiety? Gazeta Krakówska 22.10.2012.

Rewers, E. 2005. Post-Polis. Wstęp do filozofii ponowoczesnego miasta. Kraków: Universitas.

Scharpf, F. W. 1997. Games real actors play. Actor-centered institutionalism in policy research. Boulder: Westview Press. Sennett, R. 2006. The Open City. In Urban Age, Housing and Urban Neighborhoods. Newspapper Essay, Berlin, November 2006.

Sintomer, Y., C. Herzberg, and A. Röcke. 2005. From Porto Alegre to Europe: Potentials and Limitations of Participatory Budgeting. Accessed October 7, 2013. http://www.participatorybudgeting.org.uk/documents/From-PortoAlegre\%20-\%20potential\%20-\%20limits\%20of\%20PB.pdf

Turner, R. H. 1983. Figure and Ground in the Analysis of Social Movements. Symbolic Interaction 6: 175-81.

Wallis, A. 1967. Socjologia wielkiego miasta. Warszawa: PWN.

Williamson, O. 1996. The Mechanisms of Governance. Oxford: Oxford University Press. 
Wyniki głosowania. 2014. Wyniki głosowania w Sopockim Budżecie Obywatelskim 26.06.2014. Accessed September 5, 2014. http://www.miasto.sopot.pl/strona/budzet_obywatelski 